\title{
Towards the Rediscovery of Québécois Publishers' Catalogues
}

History of the Book and Bibliographical Databases

À la redécouverte des catalogues d'éditeurs québécois : histoire du livre et bases de données bibliographiques

Descubriendo los catálogos de editores quebequenses: Historia del libro y bases de datos bibliográficas

\section{Josée Vincent}

Translator. Michelle Arriss, Delaina Haslam and Séverine Sofio

\section{(2) OpenEdition}

\section{Journals}

Electronic version

URL: http://journals.openedition.org/bssg/241

DOI: $10.4000 /$ bssg.241

ISSN: 2490-9424

Publisher

Presses universitaires de Vincennes

\section{Electronic reference}

Josée Vincent, "Towards the Rediscovery of Québécois Publishers' Catalogues", Biens Symboliques / Symbolic Goods [Online], 2 | 2018, Online since 12 April 2018, connection on 04 March 2021. URL: http://journals.openedition.org/bssg/241 ; DOl: https://doi.org/10.4000/bssg.241 


\section{À la redécouverte des catalogues d'éditeurs québécois}

Histoire du livre et bases de données bibliographiques
Towards the Rediscovery of Québécois Publishers' Catalogues

History of the Book and Bibliographical Databases

\author{
Josée Vincent \\ traduction | translation \\ Michelle Arriss | Delaina Haslam | Séverine Sofio
}

\section{Comment est né le projet de base de données ?}

Développée pour rendre compte des phénomènes liés à l'écrit, tant dans leurs dimensions culturelles qu'économiques ou politiques, l'histoire du livre a toujours privilégié les approches quantitatives. Les premiers travaux de Daniel Mornet sur Les Origines intellectuelles de la Révolution française (1933), ou de Lucien Febvre et Henri-Jean-Martin sur L'Apparition du livre (1999-1958) traduisaient déjà la volonté d'appréhender de vastes corpus plutôt que de se limiter à quelques titres canoniques. Mais l'utilisation de bases de données, à partir des années 1990, a littéralement transformé la discipline en facilitant le traitement quantitatif et en multipliant ses possibilités.

\section{How did the database project begin?}

The history of the book was developed to take into account phenomena related to written works, as much in their cultural as in their economic or political dimensions; for this reason, it has always privileged quantitative approaches. The early work by Daniel Mornet in Les Origines intellectuelles de la Révolution française (1933), or Lucien Febvre and Henri-Jean Martin in L'Apparition du livre (1999/1958) already conveyed the desire to comprehend vast corpora rather than be limited to a few canonical titles. However, as of the 1990s, the use of databases transformed the discipline by facilitating the quantitative process and multiplying its possibilities. 
Au Québec, les membres du Groupe de recherche sur l'édition littéraire au Québec (GRÉLQ) ${ }^{1}$, fondé en 1982, ont d'emblée eu recours à diverses bases de données qu'ils ont pour la plupart eux-mêmes fabriquées. C'est le cas notamment des catalogues d'éditeurs, qui ont servi de socle au grand projet d'Histoire de l'édition littéraire au Québec au $x x^{e}$ siècle. Conçus par des littéraires, à un moment où l'utilisation de tels outils n'était pas chose courante, l'histoire de ces catalogues traduit en quelque sorte celle des débuts des humanités numériques.

Dirigés par Jacques Michon et Richard Giguère, les premiers travaux des membres du GRÉLQ ont porté sur l'édition littéraire au Québec pendant la Seconde Guerre mondiale, une période particulièrement riche sur le plan éditorial (Michon 2004). Rappelons qu'à partir de 1940, les éditeurs français et belges, paralysés par l'Occupation, ne sont plus en mesure d'approvisionner les marchés francophones à l'étranger. Au Québec, où plus des trois quarts de la production est importée d'Europe, la pénurie de livres frappe durement. Mais des mesures exceptionnelles ${ }^{2}$, qui viennent préciser le mode d'application de la loi sur le droit d'auteur en temps de guerre, sont prises pour permettre aux maisons d'édition québécoises de pallier ces manques. Les entreprises existantes ne suffisant pas à la tâche, de nouvelles maisons d'édition voient

Aujourd'hui le Groupe de recherches et d'études sur le livre au Québec.

2 «Les Arrêtés en conseil sur les brevets, le droit d'auteur et les marques de commerce adoptés en septembre et octobre 1939 permettent aux éditeurs canadiens de reproduire, conformément à la loi, tous les ouvrages publiés en territoire ennemi. À partir de juin 1940, cette règlementation du gouvernement fédéral s'applique à toute la France sans distinction de zone » (Michon $2004: 23$ )
In Quebec, the members of the Groupe de recherche sur l'édition littéraire au Québec (GRÉLQ), ${ }^{1}$ founded in 1982, used various databases since the beginning, and they themselves designed most of these databases. Such is the case notably with publishers' catalogues which served as a platform for the major Histoire de l'édition littéraire au Québec au $x^{e}$ siècle project (History of literary publishing in twentieth-century Quebec). Conceived by literary scholars at a time when the use of such tools was not yet commonplace, the history of these catalogues translates into, in a certain way, the history of the beginnings of digital humanities.

Led by Jacques Michon and Richard Giguère, the first works by the GRÉLQ members focused on literary publishing in Quebec during World War II, which was a particularly fertile era in terms of publishing (Michon 2004) considering that as of 1940, French and Belgian publishers, paralyzed by the Occupation, were in no position to supply foreign francophone markets. In Quebec, where more than three quarters of production was imported from Europe, the scarcity of books hit hard. However, exceptional measures ${ }^{2}$ stipulating the enforcement of laws governing copyright in times of war were put in place to allow Québécois publishing houses to offset these shortages. Because there were not enough existing companies to cope with the task, new publishing houses came into being. Their production took three forms: republishing ${ }^{3}$ existing titles; publishing texts produced by Québécois authors; and

1 Today called the Groupe de recherches et d'études sur le livre au Québec.

2 "The orders in council for patents, copyright, and trademarks, adopted in September and October 1939, allowed Canadian publishers to reproduce, in accordance with the law, all works published in enemy territory. As of June 1940 , this federal government ruling applied to all of France regardless of zone" (Michon 2004: 23).

3 Compensatory amounts would be deducted and then deposited in funds with a view to being redistributed to European publishers at the end of the conflict. 
le jour. Leur production prendra trois formes : la réédition ${ }^{3}$ de titres existants, l'édition de textes produits par des auteurs québécois et l'édition de textes d'écrivains en exil. Outre les librairies et les institutions locales, les éditeurs québécois desservent les marchés américains, africains et sud-américains. Mais à la fin de la guerre, les entreprises européennes renouent avec leurs clientèles étrangères. Privés de leurs débouchés, la majorité des éditeurs québécois sont contraints d'abandonner le métier.

C'est pour rappeler cet épisode marquant de l'histoire du livre que les chercheurs du GRÉLQ se sont mis au travail. Or, ils ont rapidement rencontré un écueil, car au Québec, l'inventaire systématique de la production nationale ne débute qu'à la fin des années $1960^{4}$. Contraints de retracer le corpus des livres édités pendant la guerre, les chercheurs ont alors décidé de reconstituer à partir de diverses sources des catalogues informatisés, afin d'en faciliter le traitement.

\section{Comment le corpus a-t-il été délimité ?}

D'abord centrés sur les ouvrages littéraires produits pendant la Seconde Guerre mondiale, les travaux des chercheurs se sont étendus du début du $x x^{e}$ siècle aux années 1980. La majorité des catalogues deséditeursquébécois actifs pendant cette période ontété reconstitués. Les publications ont été retracées parmi des collections privées et institutionnelles, notamment celles des bibliothèques

3 Des sommes compensatoires seront prélevées puis versées dans un fonds en vue d'être redistribuées aux éditeurs européens à la fin du conflit.

4 La Bibliothèque nationale du Canada, première instance à qui est revenue la responsabilité de cet inventaire, est fondée en 1953. En 1967, la Bibliothèque nationale du Québec est créée, notamment pour assurer la constitution et la préservation d'une collection québécoise nationale. La loi sur le dépôt légal

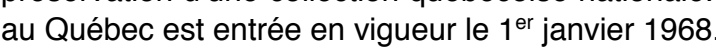

publishing the texts of writers in exile. In addition to bookshops and local institutions, Québécois publishers served American, African, and South American markets. At the end of the war, however, European companies reconnected with their foreign clientele. Deprived of their outlets, the majority of Québécois publishers were forced to abandon the profession.

It was in order to recall this significant episode in the history of the book that GRÉLQ researchers set to work. They rapidly encountered a stumbling block, though, because in Quebec the systematic inventory of national production did not begin until the end of the 1960s. ${ }^{4}$ Compelled to retrace the corpus of books published during the war, the researchers decided at that time to build digital catalogues using various sources in order to facilitate their processing.

\section{How was the corpus defined?}

At first centered on literary works produced during World War II, the work of the researchers extended to covering the beginning of the twentieth century through to the 1980s. The majority of the catalogues of Québécois publishers active during this period were reconstituted. Publications were located among private and institutional collections, especially those of university, municipal, and government libraries. Faced with an absence of publishing archives, researchers also used secondary sources such as

4 The National Library of Canada, the primary authority to whom the responsibility for this inventory fell, was founded in 1953. In 1967, the Bibliothèque nationale du Québec was created in particular to ensure the forming and preservation of a Québécois national collection. The Act respecting the Legal Deposit of Publications in Quebec came into effect 1 January 1968. 
universitaires, municipales et gouvernementales. Confrontés à l'absence d'archives éditoriales, les chercheurs ont aussi utilisé des sources secondaires, telles les journaux, les magazines, les revues et des matériaux publicitaires ("vient de paraître », catalogue promotionnels, etc.). Enfin, de nombreuses entrevues ont été menées auprès des éditeurs toujours en vie. Produits pour recenser et analyser cette masse documentaire, des entrevues, des index, des bibliographies et des répertoires informatisés sont aujourd'hui encore mis à la disposition des chercheurs.

\section{Quel est l'horizon disciplinaire ?}

Les catalogues d'éditeurs ont été conçus à partir d'un modèle bibliographique traditionnel adapté aux besoins des chercheurs. L'image suivante offre un aperçu de ce modèle, dans son état actuel :

Aux champs bibliographiques usuels (auteur, éditeur, date de publication, etc.) s'ajoutent des rubriques contenant des informations liées au support (reliure, format), au paratexte (mention de responsabilité, illustration, préfaces, etc.), à la fabrication (imprimeur, tirage, réédition, réimpression), à la diffusion (prix, point de vente), à la distribution (nom du distributeur) et à la lecture (ex libris, imprimatur, etc.). Chaque description a été rédigée « livre en main », à partir d'un ou de plusieurs exemplaires, chacun pouvant présenter des éléments différents, voire inédits dans le cas des exemplaires annotés. Les catalogues répondent ainsi à certaines exigences de la bibliographie analytique (Bowers 1950), même s'ils n'atteignent pas le degré de précision exigé pour la description de manuscrits et de livres anciens. journals, magazines, reviews, and advertising material (on new publications, promotional catalogues, etc.). Finally, numerous interviews were conducted with publishers who were still alive at the time. Produced in order to record and analyse this mass of documents, computerized indexes, interviews, bibliographies, and digitalized references are still today made available to researchers.

\section{Is the design of the database supported by a specific theory and/or discipline?}

The catalogues of publishers were conceived according to a traditional bibliographical model adapted to the needs of the researchers. The image below provides a general idea of this model in its current form:

Beside the customary bibliographical fields (author, publisher, date of publication, etc.) rubrics were added containing information associated with the medium (binding, format), paratext (statement of responsibility, illustration, prefaces, etc.), manufacture (printer, print run, re-publication, re-print), circulation (price, point of sale), distribution (name of distributor), and with reading (ex libris, imprimatur, etc.). Each description was entered using one or several copies of the book, each copy capable of presenting a variety of elements, which sometimes hadn't even been published before in the case of annotated copies. The catalogues thus fulfill certain analytical bibliographical requirements (Bowers 1950), even if they do not achieve the degree of precision required for the description of manuscripts and rare books. 
Figure 1. Interface de « recherche avancée » dans la base de données des catalogues d'éditeurs sur le site du GRÉLQ.

\begin{tabular}{|c|c|c|}
\hline RECHERCHE AVANCÉEE & & \\
\hline |auteur(s): & & \\
\hline & & 0 \\
\hline Titro: & & \\
\hline & & क) \\
\hline sous-titre: & & \\
\hline & & 0 \\
\hline Nummaro toma / volumm : & & \\
\hline & & क \\
\hline Autres éléments bibliographiques & Autres données & \\
\hline Collection: & coto: & \\
\hline \% & & - \\
\hline Numaro dans la collisection : & Genre: : & \\
\hline - & - Rechercher... & + \\
\hline Mention dreatition ?: & Porrtexts sationalal ?: & \\
\hline - & & - \\
\hline Ving: & Discours protacta(5) ?: & \\
\hline \% & & क \\
\hline Eattour: & Typographns:(s) / IIUstrattion(s) ?: & . \\
\hline \% & & - \\
\hline Annes: & Aasptation?: & 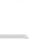 \\
\hline$\phi$ & & Q \\
\hline Pags: : & Trasuction ?: & \\
\hline 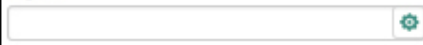 & & \% \\
\hline LIsu Gimpresssion : & Format: & \\
\hline - & & क् \\
\hline Imprimeur: & Prix: & \\
\hline \% & & क् \\
\hline Trage : & sources?: & \\
\hline - & & - \\
\hline Dats Gracheve Gimprimar : & & $=$ \\
\hline 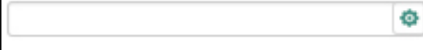 & Auteur & \\
\hline Copyrignt I Ioppot logal : & Dates vitalas: & \\
\hline$\phi$ & 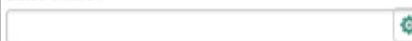 & क) \\
\hline ISBN: & $\operatorname{sex} \theta:$ & \\
\hline \% & 6 & क \\
\hline & Agg: & \\
\hline & & क \\
\hline & Ligu de nalssancos: & \\
\hline & 6 & क् \\
\hline & Pseudonyma ?: & \\
\hline & & - \\
\hline Note(s) : & & \\
\hline & 6 & 0 \\
\hline
\end{tabular}


Le modèle inclut en outre des indications de genre et des données sur les auteurs. Très utiles, les mentions de genre permettent de mesurer l'évolution du catalogue en regard des catégories littéraires (roman, théâtre, poésie, etc.) et des secteurs éditoriaux (religieux, jeunesse, littéraire, etc.). Les champs de spécialisation et les stratégies éditoriales des maisons d'édition sont ainsi mises en évidence. Par exemple, tandis qu'on réédite des classiques et des ouvrages pour la jeunesse aux Éditions Variétés, on privilégie les essais et les romans des écrivains locaux et exilés aux Éditions de l'Arbre. Quant aux informations biographiques, elles offrent le portrait d'un groupe qui inclut tous les auteurs, des têtes d'affiches aux écrivains les plus obscurs. Leur traitement quantitatif peut révéler la présence de réseaux constitués en fonction de l'âge, du sexe, de la profession ou de la nationalité. II révèle aussi, dans le cas des œuvres en réédition, les écrivains qui ont marqué leur époque, même s'ils sont aujourd'hui oubliés.

\section{Quels logiciels avez-vous utilisés pour bâtir l'infrastructure de la base de données et, le cas échéant, pour son exploitation statistique?}

L'élaboration des catalogues d'éditeurs s'est échelonnée sur trois décennies, des années 1980 auxannées2000. Aprèsquelques essais, les chercheurs ont opté pour le logiciel File Maker qui répondait aux besoins immédiats et qui était aussi simple à apprendre qu'à utiliser. Compte tenu de leurs ressources financières limitées, les chercheurs devaient en effet se débrouiller sans l'appui d'un informaticien.

Les catalogues étaient produits séparément, l'objectif de départ étant de produire des monographies pour chacune des maisons d'édition. Au fil du temps, certains chercheurs ont adapté le modèle en ajoutant des rubriques ou des éléments de saisie automatique.
The model also includes information concerning genre and details about authors. The genre indicators are particularly useful, making it possible to trace the evolution of the catalogue with regards to literary categories (novel, theatre, poetry, etc.) and of publishing sectors (religion, children, literary, etc.) The fields for specialization and publishing house strategies are, in this way, apparent. For example, while the Éditions Variétés republished classics and books for children, the Éditions de l'Arbre privileged essays and novels of local and exiled authors. The biographical information, for its part, offers the portrait of a group that includes all authors, from the most renowned to the most obscure. Their quantitative processing can disclose the existence of networks according to age, sex, profession, or nationality. It also reveals, in the case of republished works, authors who left their mark on their era even if today they have been forgotten.

\section{Which software programs were used to build the database infrastructure and, as the case may be, to treat the data statistically?}

The development of the publishers' catalogues was spread out over three decades, from the 1980s through to the 2000s. After a few attempts, researchers opted for File Maker software, which responded to their immediate needs and was simple to learn and use. Because their financial resources were limited, they had no

choice but to manage without the help of a computer technician.

The catalogues were produced separately, the purpose from the start being to produce monographs for each publishing house. Over time, certain researchers adapted the model by adding rubrics or automatic data-entry elements. In doing so, however, they 
Mais ce faisant, ils ont compromis l'uniformité des catalogues et, par conséquent, ont anéanti la possibilité de les interroger simultanément. Par ailleurs, le fait que plusieurs personnes procèdent à la saisie des données, a multiplié le risque d'erreur. D'autres difficultés liées à l'utilisation de File Maker sont survenues au fur et à mesure que de nouvelles versions du logiciel étaient commercialisées. L'obligation d'acheter continuellement de nouvelles licences est rapidement apparue comme une contrainte lourde. L'obsolescence des premières versions est aussi devenue une source d'inquiétude, puisque le transfert des données d'une version à l'autre présentait toujours un risque de corruption ou de perte d'informations. Mais le principal écueil demeurait l'impossibilité de diffuser ces bases de données en ligne. Or, au milieu des années 2000, le partage des données était devenu une priorité dans le milieu de la recherche et la création de plateformes web permettant d'héberger les bases de données, une nécessité.

C'est à ce moment que la décision a été prise de ne plus utiliser le logiciel File Maker et de se tourner vers MySQL. La plupart des bases de données documentaires, soit les index, les bibliographies et les répertoires, ont alors été converties puis mises en ligne. Dans le cas des catalogues d'éditeurs, un travail de révision et d'uniformisation a été entrepris, mais n'a pu être mené à terme, faute de ressources. Les catalogues plus complets, ainsi que ceux jugés les plus pertinents pour la recherche ont tout de même été transférés, malgré leurs lacunes et les erreurs qu'ils pouvaient contenir. Net avantage, il est maintenant possible d'interroger simultanément tous les catalogues et même d'intégrer toutes les bases de données dans une même requête pour croiser les résultats. compromised the uniformity of the catalogues and, consequently, ruined the possibility of searching them simultaneously. Furthermore, the fact that several people proceeded to enter data, multiplied the chances of mistakes being made. Other difficulties related to the use of File Maker occurred as and when new versions of the software were released. The obligation to continually purchase new licences quickly became a serious constraint. The obsolescence of the early versions also became a source of concern since the transfer of data from one version to the next always presented a risk of corruption or loss of data. However, the main pitfall remained the impossibility of making these databases available online. By the mid-2000s, the sharing of data had become a priority in research and the creation of online platforms where databases could be stored, had become a necessity.

It was then that the decision was made to no longer use File Maker and to change over to MySQL. Most of the documentary databases, that is, the indexes, bibliographies, and references, were thus converted and made available online. In the case of publishers catalogues, a revision and standardization project was undertaken, but could not be completed due to a lack of resources. The most complete catalogues as well as those considered to be the most pertinent for research were nonetheless transferred, despite their gaps and any errors they might contain. A clear benefit is the fact that it is now possible to search all catalogues simultaneously and even integrate all databases into one search in order to crossreference the results. 


\section{Pourriez-vous donner en exemple un ou deux résultats scientifiques (attendu ou surprenant) obtenus à l'aide de la base de données ?}

Les catalogues d'éditeurs ont permis la réalisation de nombreuses monographies prenant la forme d'articles, de mémoires, de thèses ou de chapitres de livre. La liste de ces réalisations ${ }^{5}$ montre combien l'analyse des catalogues s'est révélée fertile. Ils sont aussi à la source de l'Histoire de l'édition littéraire au Québec au XX siècle (Michon 1999, 2004, 2010), une synthèse magistrale qui demeure la référence incontournable dans le domaine. Mais les catalogues ont aussi servi à d'autres fins. Les données concernant le paratexte ont été mobilisées entre autres par Marie-Pier Luneau, qui s'est intéressée aux discours préfaciels (2016), et Sophie Drouin dont la thèse à venir porte sur les illustrations. D'autres formes d'utilisation sont envisagées, notamment en géolocalisation.

Les catalogues d'éditeurs conservent encore aujourd'hui leur intérêt, puisqu'à ce jour aucun autre outil bibliographique ne recense la production des éditeurs actifs avant les années 1960. Leur développement dépend néanmoins des ressources financières allouées aux chercheurs et, en ce sens, leur pérennité n'est certainement pas assurée. Mais il dépend aussi de la volonté des chercheurs d'explorer toutes les possibilités qu'ils offrent et vu sous ce jour, l'avenir demeure prometteur.

Université de Sherbrooke - Département des lettres et communications

5 Voir notamment la liste des mémoires et des thèses : https://www. usherbrooke.ca/grelq/theses-et-memoires/.

\section{Could you offer one or two examples of scientific (whether consensual or surprising) results obtained with the help of the database?}

The publishers' catalogues have enabled the creation of a number of monographs in the form of articles, dissertations, theses, and book chapters. The list of these documents shows how rich these catalogues have proven to be. They are also at the heart of the Histoire de l'édition littéraire au Québec au XX siècle (Michon 1999 , 2004, 2010), a brilliant synthesis that remains an indispensable reference in the field. But the catalogues have served other purposes. Data relating to the paratext has been used among others by Marie-Pier Luneau, who was interested in prefatory discourse (2016), and Sophie Drouin whose thesis in progress focuses on illustrations. Other applications are envisaged, notably in geolocalization.

Publishers' catalogues are still relevant today because, up until now, no other bibliographical tool records the production of publishers who were active prior to the 1960s. Nevertheless, their development depends on financial resources allotted to research and, in this sense, their perpetuity is certainly not guaranteed. But their development also depends on the willingness of researchers to explore all the possibilities that they offer, and from this perspective the future remains promising. 


\section{Références bibliographiques}

BOWERS Fredson (1950). Principles of Bibliographical Description. Princetown, Princetown University Press.

FebVRE Lucien \& MARTIN Henri-Jean (1999-1958). L'Apparition du livre. Paris, Albin Michel.

Luneau Marie-Pier \& Saint-Amand Denis (dir.) (2016). La Préface. Formes et enjeux d'un discours d'escorte, Paris, Classiques Garnier.

MıCHON Jacques (dir.) (1999). Histoire de l'édition littéraire au Québec au XXe siècle. "La naissance de l'éditeur. 1900-1939 », volume 1. Montréal, Fides.

MıCHON Jacques (dir.) (2004). Histoire de l'édition littéraire au Québec au $x X^{e}$ siècle. "Le temps des éditeurs. 1940-1959 », volume 2. Montréal, Fides.

MıCHON Jacques (dir.) (2010). Histoire de l'édition littéraire au Québec au $x x^{e}$ siècle. «La bataille du livre. 1960-2000 », volume 3. Montréal, Fides.

\section{References}

BOWERS Fredson (1950). Principles of Bibliographical Description. Princetown, Princetown University Press.

Febvre Lucien \& MARTIN Henri-Jean (1999-1958). L'Apparition du livre. Paris, Albin Michel.

Luneau Marie-Pier \& Saint-Amand Denis (eds.) (2016). La Préface. Formes et enjeux d'un discours d'escorte, Paris, Classiques Garnier.

MıcHon Jacques (ed.) (1999). Histoire de l'édition littéraire au Québec au XXe siècle. "La naissance de l'éditeur. 1900-1939," volume 1. Montréal, Fides.

MicHON Jacques (ed.) (2004). Histoire de l'édition littéraire au Québec au XXe siècle. "Le temps des éditeurs. 1940-1959," volume 2. Montréal, Fides.

MıcHON Jacques (ed.) (2010). Histoire de l'édition littéraire au Québec au xx siècle. "La bataille du livre. 1960-2000," volume 3. Montréal, Fides. 